\title{
ACTIVITY MANAGEMENT OF THE ACTION PLAN FOR A SUSTAINABLE FIGHT AGAINST TAX FRAUD AND TAX EVASION IN SLOVAKIA AS COMPARED WITH THE EU
}

The research is focused on determining the tax fraud ways and analyzing the amount of tax evasion. The authors stress the need to strengthen the fight against tax frauds and tax evasions in the EU overall and in Slovak Republic in particular. For achieving the aim of the paper the systems and mechanisms of tax carrying out control were investigated. The authors analyzed the activities of tax authorities and demonstrated how these bodies can fight with tax fraud and tax evasions. Analyzing the data from the VIAS and the Eurostat systems the tax evasions in the Slovak Republic, in some other EU member states and their share in the total tax duty were compared. Within this part, the authors proposed the system of international tax information exchange of EU member states and the VIES system which will work with information about intercommunity businesses in EU member states and the Eurostat system. The results of cluster analysis showed that within the EU member states, by the estimated volume of tax evasions (in particular, the value-added tax as a significant share of the total taxes duty) Slovakia takes one of the lowest places among the EU member states. Since value-added tax offers the most opportunities to avoid tax duties and provides the biggest room to make tax frauds and connected tax evasions the authors determine the mechanism of the overall tax administration in the Slovak Republic and some EU member states. Increasing the effectiveness of the fight against tax evasions and frauds can be realized by taking the measures of the compulsory establishment of an equal business accounts, the establishment of the registrar of fines of individual taxpayers, an introduction of a unified valueadded tax rate and in some cases the cancellation of VAT and the introduction of a turnover tax.

Keywords: tax; tax payers; tax fraud; tax evasion; VAT; Slovakia; the European Union.

Introduction. Each country fights against shadow economy, tax frauds and tax evasion. Coordination and cooperation in the battle against organized tax offenders at the international level is a necessity. For such cooperation and consequent improvement of tax discipline and reduction of tax fraud cases and tax evasions, the European Union has created "The action plan to strengthen the fight against tax fraud and evasion in EU". In June 2012, the government of Slovak Republic approved "Action Plan to Combat Tax Fraud in the Years 2012 to 2016 ". Its priority aim is more effective tax collection, especially value-added tax. The plan also includes a time schedule to introduce the regulations which are divided into three stages.

This plan also contains 50 measures within three areas:

1. the area of financial, criminal, tax and commercial law; 
2. cross-section activities;

3. operational activities (by the authorities responsible for criminal proceedings) (Lénartová, 2013).

Theoretical part. National Criminal Agency (hereinafter referred to as "NAKA") was established by connecting the Bureau of Combating Organized Crime and the Bureau of the Fight against Corruption on 1 December 2012. NAKA is one of the bodies which is run by a director who is inferior to its president. The activities of NAKA focus its attention mainly on revealing, investigation, and documentation of the most serious cases of organized criminal activity, criminal activity connected to corruption, illegal financial operations, public auction, public procurement etc.

The National Criminal Agency of the Slovak Police Force Slovakia is divided into the following sections:

1. National Anti-Corruption Unit;

2. National Financial Police Unit;

3. Financial Police Intelligence Unit;

4. National Counter-CrimeUnit;

5. National Anti-Drug Squad;

6. Investigation Department and Rapid Response Team;

7. Department of the Management Support and International Cooperation (Act. 333/2011 Coll.).

The National Financial Police Unit focuses on the fight against economic crime offences. To fulfil this reason, it cooperates with the bodies of the Financial Administration of the Slovak Republic. The National Financial Police Unit investigates and pays its attention mainly to:

- cases of economic crime offences (within the economic activity, they are mainly tax crime offences;

- not paying taxes and insurance, tax frauds, tax and insurance reduction);

- cases of property crimes;

- illegal import of goods;

- sham export of goods;

- carousel tax frauds;

- evasions and frauds connected to invoicing and bookkeeping;

- tax frauds connected to the import of goods from the third countries;

- fake intracommunity goods deliveries (businesses within one inner market of the EU member state);

- avoiding the registration for VAT;

- illegal financial operations and actions in the field of financial and capital market;

- counterfeiting and unauthorised money production (Act no. 333/2011 Coll.).

European Anti-fraud Office (OLAF). The budget of the European Union finances different projects and programmes determined to improve the life of the citizens of the EU member states and the third countries, but not paying taxes, payments, customs, and illegal use of EU finances restricts this purpose. OLAF contributes to the best possible use of money of taxpayers by effective investigation of frauds, corruption and breaking the rules within European institutions (ec.europa.eu).

Based on the European Commission's decision of 28 April 1999, the European anti-fraud office OLAF (hereinafter referred to as Office) was established. At the head of the office, there is a general director who is appointed by the European Commission. The office closely cooperates with judicial offices and the police.

The mission of the European Anti-fraud Office is:

1) to carry out investigation competences of the European Commission (herein after referred to as Commission) by carrying out external investigations for the purpose of intensifying the fight against illegal activities, corruption, frauds and other antilegal actions which negatively affect the financial interests of the EU (revenues, expenses, property within the EU budget etc.), 
2) to be responsible for revealing and clarifying important factors related to the performance of service tasks which could represent the violation of the duties of the community employees and office workers and at the same time, they would probably lead to criminal offence from the side of the members of the EU bodies and institutions;

3) to prevent frauds based on the preparation of legal and regulating incentives of the Commission;

4) related to the fight against frauds, to be responsible for operational activities of the Commission (e.g. collection and analysis of information, the development of the required infrastructure). (the European Commission's decision 1999/352/ES, ESUO).

OLAF investigations:

a. External Investigations.

The office carries out inspections and controls in compliance with legal tools, agreements about cooperation and mutual help at places in the EU member states, in the third countries and in the territories of international organizations. When investigating corruption, frauds and other illegal acts focused on against financial interests of EU, the Office can carry out official supervision of economic subjects on the spot. During the investigation, the Office has the right to access all information in the databases which are related to it.

b. Internal Investigations.

The Office carries out administrative inspections in institutions, authorities, bodies, offices, and agencies. It has the right to unannounced access to their premises and to any data and information that the institutions, agencies, offices and bodies work with. In the case of risking the disappearance of the documents, the Office has the right to make copies, statements or to ensure the needed documents. At the same time, the Office can require written or spoken information from employees, clerks, the members of the bodies or directors (The regulation of the European Parliament and Council no. 883/2013).

VIES and EUROSTAT systems. VIES System. It is a system that collects, exchanges and preserves information about the number of intracommunity businesses in the EU member states which are carried out by persons identified for VAT. At the same time, it enables to verify the validity of the VAT identification numbers issued in different EU states and to exchange information in an automated way.

The division of the VIES information system at the L1 level:

- L1QD - it is a monthly exchange of the sets of information of Slovak payers about the values of delivered services and goods to persons identified for VAT in other EU member states, the total value for a respective month and for a state-related value of the acquisitions of individual persons registered for VAT within Slovakia;

- L1F1 - means a total value of the acquisitions of individuals in Slovakia from a supplier or from a given EU member state;

- L1F2 - represents a total value of all acquisitions of one acquirer in Slovakia from given EU member states.

The division of the VIES information system at the L2 level:

- L2F1 - represents a total value of all acquisitions of special acquirers in Slovakia who received services or goods from a given supplier from a given EU member state;

- L2F2 - represents a set of acquisitions which were carried out by a Slovak acquirer from certain suppliers.

VIES information system at the L3 level:

This level includes spontaneous information or information on request concerning a particular case. They are implemented through an electronic form. (Srnková 2013, Korauš et al. 2017 b).

EUROSTAT is a Statistical Office of the European Union which was established in 1953. Its role is to provide a high-quality statistical information service to the European Union. In order to collect all statistical data from individual national statistical institutes of $28 \mathrm{EU}$ member states, Eurostat uses unified rules. After 
their collection in a required form comes consolidation and harmonization dependent on the specifics of each country. Beyond the borders of Europe, Eurostat plays a leading role in the harmonization of the statistical systems with Japanese, Canada or international organizations (e.g. UN)(www.europskaunia.sk).

Data and methodology. The following tables and graphs show tax evasions in the EU member states and tax evasion in Slovakia

Table 1 - Tax evasions in Slovakia in mil. $€$ (ec.europa.eu)

\begin{tabular}{|c|c|c|c|}
\hline \multirow{2}{*}{ Tax gap in Slovakia in mil. $€$} & \multicolumn{3}{|c|}{ Year } \\
\cline { 2 - 4 } & $\mathbf{2 0 1 3}$ & $\mathbf{2 0 1 4}$ & $\mathbf{2 0 1 5}$ \\
\hline Total tax duty & 6615 & 6795 & 7484 \\
\hline Incomes from VAT & 4221 & 4182 & 4711 \\
\hline Tax gap & 2393 & 2613 & 2773 \\
\hline Tax gap as a share on total tax duty & $36 \%$ & $38 \%$ & $37 \%$ \\
\hline Tax gap as a share on GDP & $3,8 \%$ & $4 \%$ & $4 \%$ \\
\hline
\end{tabular}

Table 2 - Tax evasions of EU member states in mil. $€$ (ec.europa.eu)

\begin{tabular}{|l|c|c|c|}
\hline \multirow{2}{*}{ EU member state } & \multicolumn{3}{c|}{ Year } \\
\cline { 2 - 4 } & $\mathbf{2 0 1 3}$ & $\mathbf{2 0 1 4}$ & $\mathbf{2 0 1 5}$ \\
\hline Austria & 2151 & 2573 & 3468 \\
\hline Belgium & 4395 & 4571 & 4970 \\
\hline Bulgaria & 554 & 385 & 604 \\
\hline Czech Republic & 3234 & 4315 & 4241 \\
\hline Denmark & 2274 & 2382 & 2566 \\
\hline Estonia & 181 & 221 & 301 \\
\hline Finland & 1716 & 2762 & 2831 \\
\hline France & 33478 & 32148 & 32233 \\
\hline Germany & 19587 & 26144 & 26909 \\
\hline Greece & 8069 & 7431 & 9763 \\
\hline Hungary & 2770 & 3351 & 3700 \\
\hline Ireland & 1811 & 1294 & 1108 \\
\hline Italy & 39793 & 31699 & 36134 \\
\hline Lithuania & 804 & 698 & 954 \\
\hline Latvia & 1297 & 1243 & 1352 \\
\hline Luxemburg & 224 & 504 & 551 \\
\hline Malta & 53 & 45 & 21 \\
\hline Holland & 3848 & 1545 & 4012 \\
\hline Poland & 3985 & 3764 & 5410 \\
\hline Portugal & 2911 & 2575 & 2764 \\
\hline Romania & 7630 & 8887 & 10348 \\
\hline Slovakia & $\mathbf{2 3 9 3}$ & $\mathbf{2 6 1 3}$ & $\mathbf{2 7 7 3}$ \\
\hline Slovenia & 361 & 356 & 326 \\
\hline Spain & 22474 & 10765 & 15197 \\
\hline Sweden & 558 & 225 & 932 \\
\hline England & 14215 & 16937 & 4987 \\
\hline & & & \\
\hline
\end{tabular}

Based on the statistics of European Commission and Eurostat, the total tax duty of Slovakia for the year 2013 was 6615 mil. $€$. The total incomes from VAT were in the sum of 4221 mil.€. The total loss from VAT collection was in the amount of 2393 mil. $€$, which is $3,8 \%$ from GDP. The share of tax frauds on total tax duty was at a level of $36 \%$. The Eurosystem defines a narrow aggregate (M1), mid aggregate 
(M2) and broad aggregate (M3) (Koraus et al.2017 a).

The end of the year 2014 meant for Slovakia a tax duty in the sum of 6795 mil. $€$ and also interannual increase by $0,5 \%$. The incomes from value-added tax was 4182 mil. $€$. In aninterannual comparison, they decreased by $9 \%$. The tax gap compared to the year 2013 rose by $22 \%$. Tax evasions were in the sum of 2613 mil. $€$ and they represented a $38 \%$ share on total tax duty. The share of a tax gap on GDP was in the amount of $4,0 \%$ with an interannual increase by $38 \%$.

The year 2015 brought $10 \%$ interannual growth of a tax duty to a sum of 7484 mil. $€$. Also, the incomes from VAT increased by $13 \%$. These incomes represented 4711 mil. $€$. The difference between a really paid tax and a tax which should have been paid was in the sum of 2773 mil. $€$. This tax loss in the year 2015 represented $37 \%$ from the total tax duty and a share of $4 \%$ on GDP.

Table 3 - Tax evasions in EU member states as a share on total tax duty in \% (ec.europa.eu)

\begin{tabular}{|l|c|c|c|}
\hline \multirow{2}{*}{ EU member states } & \multicolumn{3}{|c|}{ Year } \\
\cline { 2 - 4 } & $\mathbf{2 0 1 3}$ & $\mathbf{2 0 1 4}$ & $\mathbf{2 0 1 5}$ \\
\hline Austria & 9 & 10 & 13 \\
\hline Belgium & 16 & 15 & 16 \\
\hline Bulgaria & 15 & 10 & 15 \\
\hline Czech Republic & 25 & 29 & 28 \\
\hline Denmark & 9 & 9 & 10 \\
\hline Estonia & 13 & 15 & 18 \\
\hline Finland & 10 & 15 & 14 \\
\hline France & 20 & 19 & 19 \\
\hline Germany & 10 & 13 & 12 \\
\hline Greece & 35 & 31 & 39 \\
\hline Hungary & 26 & 28 & 30 \\
\hline Ireland & 15 & 11 & 10 \\
\hline Italy & 31 & 25 & 27 \\
\hline Lithuania & 42 & 37 & 41 \\
\hline Latvia & 40 & 36 & 36 \\
\hline Luxemburg & 8 & 17 & 17 \\
\hline Malta & 10 & 9 & 4 \\
\hline Holland & 9 & 3 & 9 \\
\hline Poland & 15 & 12 & 15 \\
\hline Portugal & 20 & 16 & 16 \\
\hline Rumania & 49 & 48 & 48 \\
\hline Slovakia & 36 & 38 & 37 \\
\hline Slovenia & 11 & 10 & 10 \\
\hline Spain & 34 & 16 & 21 \\
\hline Sweden & 2 & 1 & 2 \\
\hline England & 13 & 13 & 13 \\
\hline & & & \\
\hline
\end{tabular}

From the overview of tax evasions in some of the EU member states (table 2) follows that the Slovak Republic increases the share of tax gap on VAT every year. Since 2013, the loss of taxes grew by about $7 \%$. As we can see, the highest tax evasions are in ltaly with more than 39 billion $€$. The second place takes France where 33 billion $€$ are missing in the budget of the country for the last observed year. After France, there is Spain with more than 22 billion $€$ and Germany with more than 19 billion $€$. In Slovakia, the loss of VAT in the last year from all observed years was more than 2 mil. $€$.

Table 3 describes percentages of tax evasions reported as a share on total tax duty. In 2013, Romania had the highest percentage and it was $49 \%$. Sweden had the lowest share of tax evasions with $2 \%$. In 
comparison to the year 2014, Romania remains at the same place with the highest share of tax evasions and it is $48 \%$ from the original $49 \%$. Sweden decreased its share to $1 \%$ from the original $2 \%$. Other countries which are at the places to the level of $10 \%$ of a tax gap are Malta (4\%) and Holland (9\%), Luxemburg (8\%), Denmark (9\%) Austria (9\%). A high risk is represented by countries like Romania (48\%), Lithuania (41\%), Greece (39\%), Slovakia (37\%), Hungary (30\%) in the year 2015.

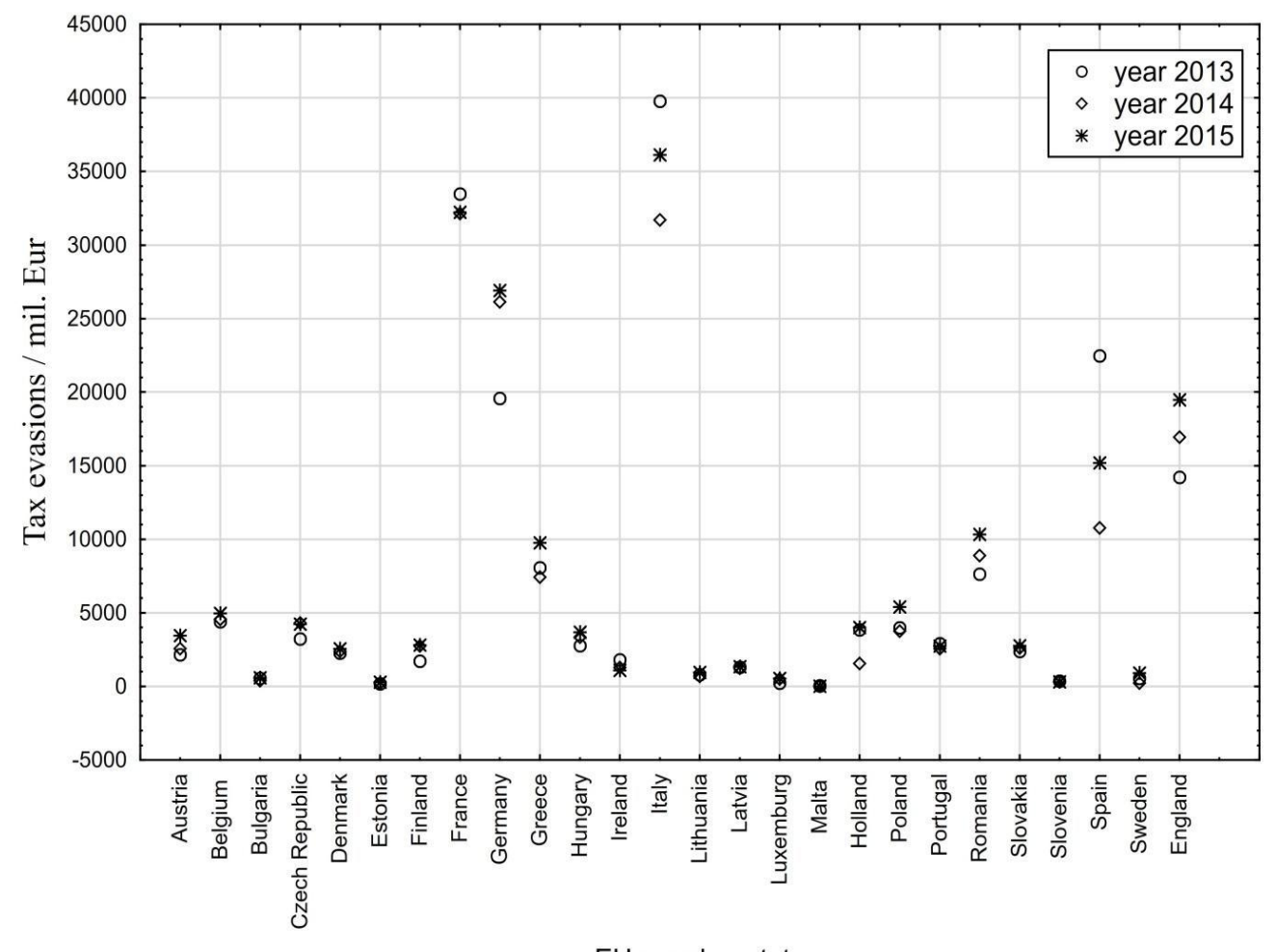

EU member state

Figure 1 - Taxevasionsof EU member states in mil. Euro (own processing)

Graphic depiction of tax evasions in some EU member states as a share on total tax duty is shown in Figure 2.

It is obvious from the given table (table 4) that the most suitable method of clustering is the method of Group Average (Unweighted Pair-Group). Even if we see that the Cophenetic Correlation value is the highest by the method of Complete Linkage (Furthest Neighbour), the lowest value of coefficient Delta $(0,5)$ is just by the method of Group Average. We can see from the results of a cluster analysis in a form of a dendrogram (Figure 3) that from the point of view of tax evasions of some of the EU member states as a share on total tax duty in \% in the period of the years $2013-2015,5$ individual groups were created. The first and the biggest group includes states like Austria, Slovenia, Denmark, Finland, Germany, England, Ireland, Belgium, Estonia, Bulgaria, Poland, Luxemburg, France and Portugal. 


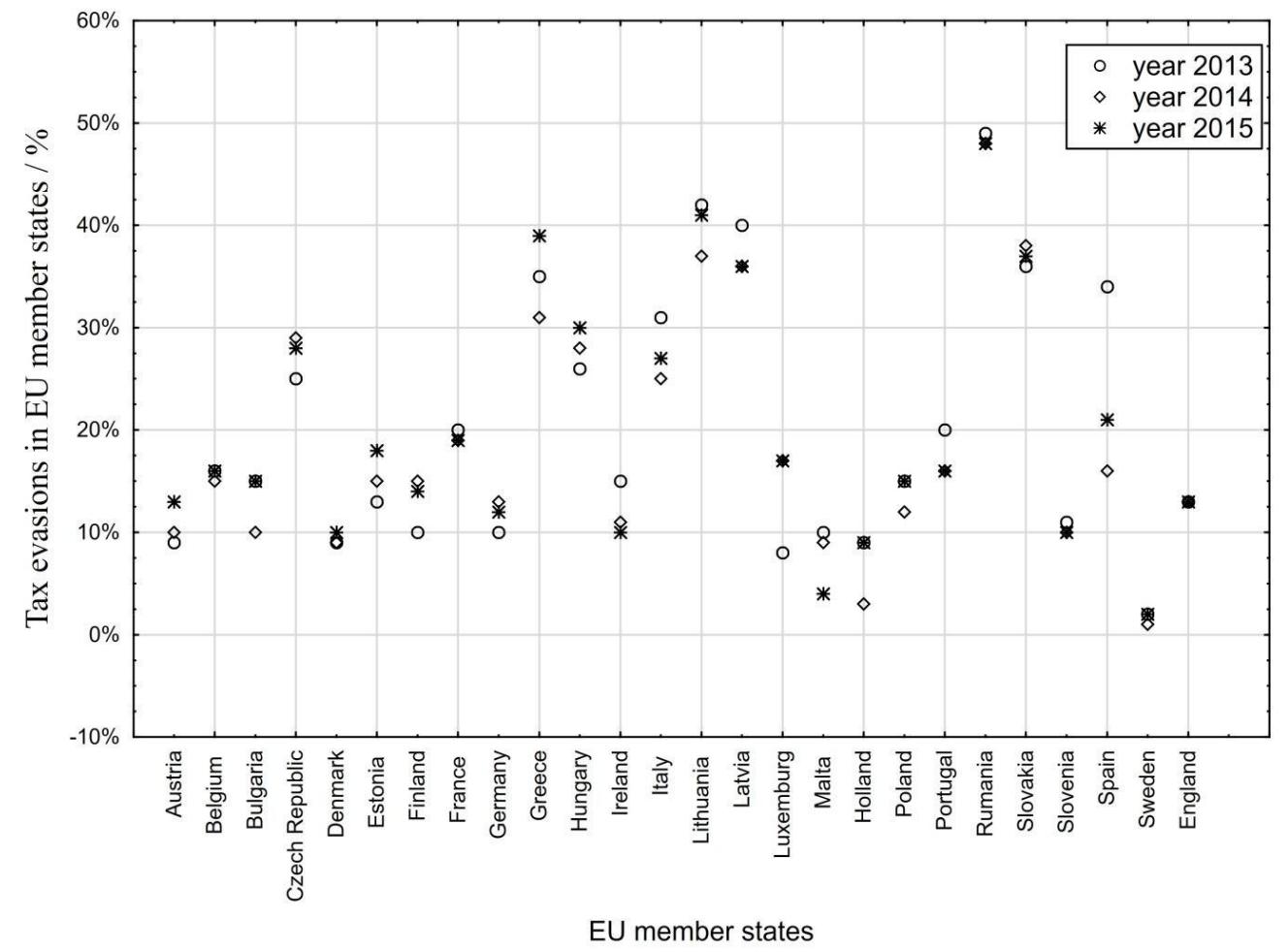

Figure 2 - Tax evasions of some EU member states as a share on total tax duty in $\%$ (own processing)

Table 4 - Indicators of the suitability of cluster analysis (own processing)

\begin{tabular}{|l|c|c|c|}
\hline Method of aggregation & Cophenetic Correlation & Delta(0.5) & Delta(1.0) \\
\hline Single Linkage (Nearest Neighbour) & 0,792619 & 1,423000 & 1,802798 \\
\hline Complete Linkage (Furthest Neighbour) & 0,828710 & 0,458201 & 0,503900 \\
\hline Simple Average (Weighted Pair-Group) & 0,808753 & 0,293198 & 0,352829 \\
\hline Group Average (Unweighted Pair-Group) & $\mathbf{0 , 8 0 9 9 0 9}$ & $\mathbf{0 , 2 8 9 9 6 0}$ & $\mathbf{0 , 3 6 3 2 2 6}$ \\
\hline Median (Weighted Pair-Group Centroid) & 0,739434 & 0,495651 & 0,533540 \\
\hline Centroid (Unweighted Pair-Group Centroid) & 0,671981 & 0,639884 & 0,857779 \\
\hline Ward's Minimum Variance & 0,664017 & 0,892569 & 0,902410 \\
\hline Flexible Strategy & 0,729750 & 0,791292 & 0,800983 \\
\hline
\end{tabular}

The second group consists of states of Malta, Holland and Sweden. The third group includes the Czech Republic, Hungary, Italy and Spain. The fourth group is created by Greece, Lithuania, Latvia and Slovakia. The last fifth group in which the development of tax evasions in the years 2013 to 2015 is different than in the other mentioned groups in Romania. 


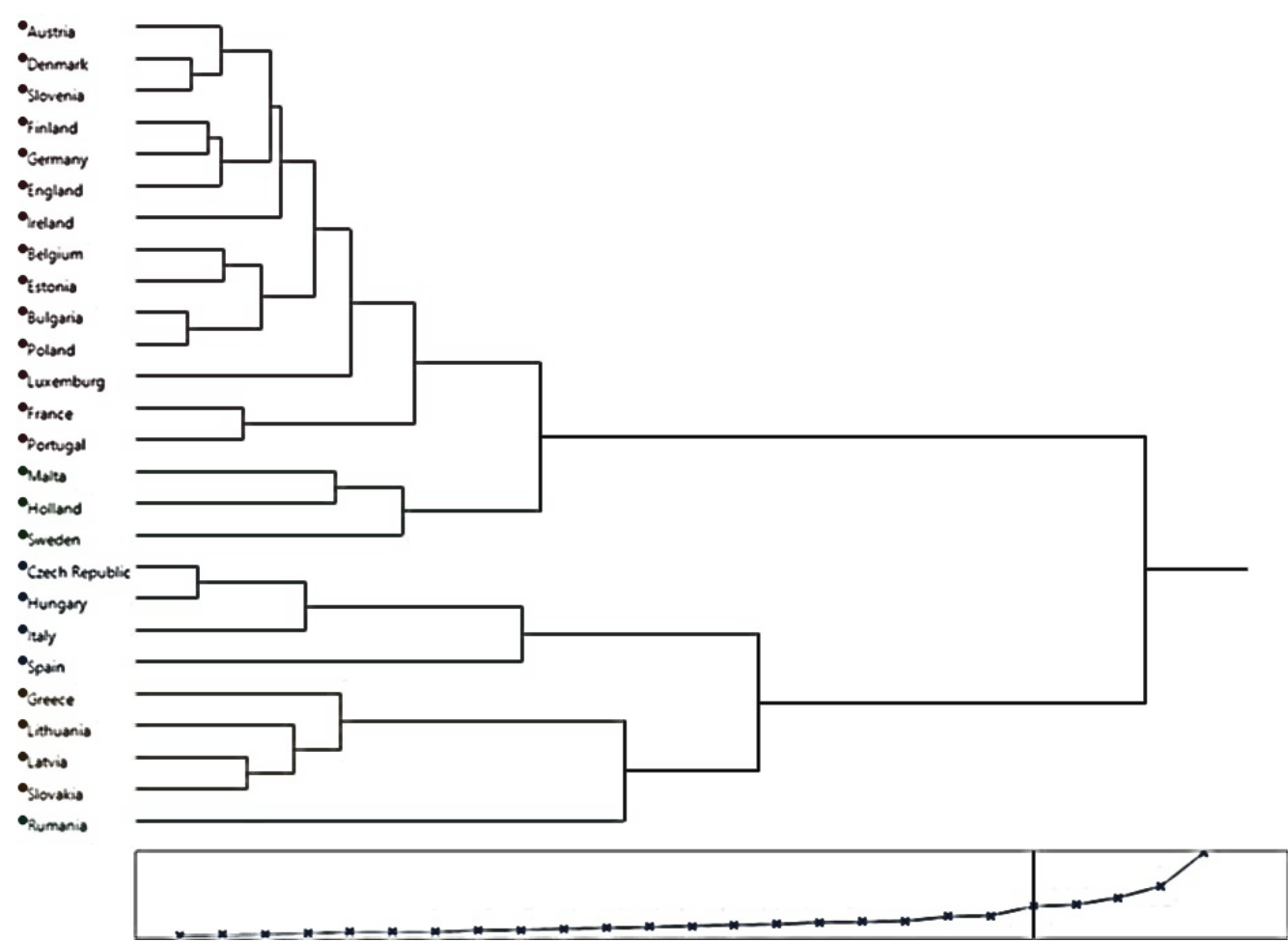

Figure 3 - Dendrogram of tax evasions in EU member states as a share on total tax duty

(Own processing)

Based on a cluster analysis in the form of a dendrogram (figure 3), we can see that from the point of view of tax evasions in some EU member states as a share on total tax duty in $\%$ in the period of the years 2013 - 2015, 5 individual groups were created. Slovakia was included into the fourth group with Greece, Lithuania and Latvia because it was reflected in the approach to tax collection in particular states as a benevolent approach to tax collection and at the same time, a benevolent approach to taxpayers control. Slovakia appeared in a group before the last one whereas there is only one more group behind it and that is Romania which is specific with approximately $48-49 \%$ share on total tax duty. We can of course state that Slovakia is not the worst country in tax evasions in the EU member states as a share on total tax duty but we must realize that we are at the bottom places with the countries from the post-socialist block together with Greece which must completely reform its tax system. These are countries with a similar average of tax evasions as a share on total duty where Lithuania has around $40 \%$, Latvia $37,3 \%$, Greece $35 \%$ and Slovakia $37 \%$ of the average for the observed period of the years 2013-2015. Therefore, Slovakia must take effective measures to fight against tax evasions because tac income creates $80 \%$ of state revenues. According to our opinion, Slovakia appeared in the fourth group of states because of the bad business environment, corruption environment and a benevolent approach to controls at a public and state administration. Therefore, Slovakia should begin to deal with measures to reduce tax evasions or to solve the situation by radical steps which we suggest in the discussion part of this paper.

Conclusion. The aim of the paper was to focus the attention to the assumption that within some EU member states, the assumed amount of tax evasions on VAT as a share on total tax duty in Slovakia will be the highest. The aim of the paper was also to point out the tax system in the Slovak Republic and the 
activity of tax authorities by carrying out the control activity and to point out the activity of its bodies in order to eliminate tax frauds and evasions in the Slovak Republic and some of the EU member states which ensure and carry out a battle against them.

In the theoretical part of the paper, we dealt with taxes and authorities which deal with them. further on, we focused on tax frauds and tax evasions. Within this part, we introduced an international tax information exchange of some EU member states, the VIES system which works with information about intracommunity businesses in EU member states and the Eurostat system - the Statistical Office of the European Union which provides mediation of information of the European Union.

The aim of the practical part of the paper was to point out the collection and the overall tax administration in the Slovak Republic and some EU member states as a comparison of a share on a total tax duty in \% with a focus on value-added tax since this tax offers the most opportunities to avoid tax duties of enterprising subjects and it provides the biggest room to make tax frauds and connected tax evasions. We can state that Slovakia is not the worst country in tax evasions among some EU member states as a share on a total tax duty.

From the cluster analysis in the form of a dendrogram (figure 3), we can see that from the point of view of tax evasions of some EU member states as a share on a total tax duty in \% during the period of the years 2013 to 2015, 5 individual groups were created. The first and the biggest group includes Austria, Slovenia, Denmark, Finland, Germany, England, Ireland, Belgium, Estonia, Bulgaria, Poland, Luxemburg, France, and Portugal. The second group consists of Malta, Holland, and Sweden. The third group includes the Czech Republic, Hungary, Italy, and Spain. The fourth group consists of Greece, Lithuania, Latvia, and Slovakia. The last fifth group in which the development of tax evasions during the period from 2013 to 2015 was different as in the other mentioned countries and that is Romania.

The paper stresses the fact that VAT is the tax which has the biggest share on tax evasions of a country in a negative way in each actual year. Since value-added tax is an excise tax, it will be paid by a citizen at last. At the same time, we can state that this tax was not in the centre of attention adequately from the side of the governments of individual countries, the Ministries of finance and neither by the tax offices themselves (financial offices), OLAF and it was "politically" tolerated to a certain extent.

In the final part of the paper, we suggested some measures which could contribute in the fight against shadow economy and which could contribute to a more effective battle against tax frauds even though they can seem to lead to a more demanding administration load.

At the level of EU member states, it is necessary to increase the effectiveness of the fight against tax evasions and frauds by taking the measures proposed by us:

a. Compulsory establishment of one business account would contribute to the payments of all invoices (received and issued) only as cashless payments. At the same time, all these invoices would have to correspond to the issued and received invoices in accounting books;

The above-mentioned measures could contribute to the abolishment of VAT control statement and at the same time, tax offices would have continuous information about business activity of particular taxpayers.

b. The establishment of the registrar of fines of individual taxpayers. For this reason, it is not possible to find out if the taxpayer got one, ten or fifty fines in a previous period as well as the amount of these fines so that consequent effective measures against tax evasions in particular taxpayer could be taken;

c. Introduction of a unified value added tax rate which would mean harmonization of taxes in the whole Eurozone in VAT. With regards to the issue of taxes, particularly the value added tax rates which are different in each EU country, this harmonization will probably not happen in the future. Therefore, it is urgent to search the ways and mechanisms of a common fight against shadow economy by more detailed information about the businesses carried out among individual states. In the first stage, it would be appropriate to introduce a unified value added tax statement in the whole Eurozone; 
d. Cancellation of VAT and the introduction of a turnover tax. We realize that it is a radical step which must be discussed at the level of all EU member states but in our opinion this step would lead to the increase of the revenues of individual countries as it is in developed world countries and mainly to stop the around 200 mil. of an annual tax evasion on VAT in the EU member states.

Acknowledgment. The contribution is the result of VEGA Project No. 1/0255/2016 The research on the possibility of optimization of process-oriented models of the financial administration management with a focus on transfer pricing and tax harmonization in the terms of EU.

Arp, R. 2013. 1001 Ideas That Changed the Way We Think. New York: Atria Books. ISBN 978-1-4767-0572-9.

Belás, J.; Chocholáková, A.; Gabčová, L. 2015. Satisfaction and loyalty of banking customers: a gender approach, Economics and Sociology, Vol. 8, No1, pp. 176-188. DOI: 10.14254/2071-789X.2015/8-1/14.

Belás, J.; Demjan, V. 2014. Bank customers satisfaction: case studies from Czech Republic. Actual problems of economics, No. 12(162), pp. 315-323.

Belás J., Sopková G. (2016), Significant determinants of the competitive environment for SMEs in the context of financial and credit risks, Journal ofl nternational Studies, Vol. 9, No 2, pp. 139-149. DOI: 10.14254/2071-8330.2016/9-2/10.

Belás,J., Bartoš,P., Ključnikov,A., DOLEŽAL,J.,(2015) "Risk perception differences between micro-, small and medium enterprises", Journal of International Studies, Vol. 8, No 3, 2015, pp. 20-30. DOI: 10.14254/2071-8330.2015/8-3/2.

Burák, E. 2004. Daňové plánovanie a daňové výdavky po prijatí nového zákona. Bratislava: EPOS. ISBN 80-8057-612-2

Brederode, F. 2009. Systems of General Sales Taxation: Theory, Policy and Practice. Holandsko: Kluwer Law International. ISBN 978-90-411-2832-4

Dobrovič, J. 2011. Trendy v manažmente daňovej správy SR v kontexte štátov V4 a Slovinska. Prešov: Prešovská univerzita v Prešove. ISBN 978-80-555-0339-4.

Dobrovič,J. et al.,2015: Hodnotenie výkonnosti manažmentu efektívnej daňovej správy SR v kontexte regiónov pred reformou daňovej správy SR s návrhom jej zefektívnenia po reforme. (Performance Evaluation of Effective Tax Administration Management of the Slovak Republic in the Regional Context before the Tax Administration Reform of the SR with a Proposal for Its Higher Effectivity after the Reform). University of Prešov, Prešov. 2.

Dvořáček, J., L. TYLL. 2010. Outsourcing a offshoring podnikatelských činností. Praha: C. H. Beck. ISBN 978-80-7400-010-

Grúň, L'. 2001. Dane včera, dnes a zajtra. Bratislava: Eurounion. ISBN 80-88984-28-9.

Ključnikov A., Sobeková Majková M., Schwendemann A., Knogler CH. (2016), Do SMEs in Slovakia face real difficulties in obtaining financing? Comparison of the studies from Slovakia and the EU, Journal of International Studies, Vol. 9, o 3, pp. 36-52. DOI: $10.14254 / 2071-8330.2016 / 9-3 / 3$.

Korauš, A.; Kaščáková, Z.; Parová, V.; Veselovská, S. 2017 a. Sustainable economic development through human resource management: social intelligence of managers and performance, Journal of Security and Sustainability Issues 6(3): 457-477. http://dx.doi.org/10.9770/jssi.2017.6.3(11)

Korauš, A., Simionescu, M., Bilan, Y., Schönfeld, J. 2017 b. The impact of monetary variables on the economic growth and sustainable development: case of selected countries, Journal of Security and Sustainability Issues 6(3): 383-390. http://dx.doi.org/10.9770/jssi.2017.6.3(5)

Kubátová, K. 2010. Daňová teorie a politika. 5. vyd. Wolters Kluwer ČR. ISBN 987-80-7357-574-8.

Lajčin,D., M. Frankovský, R. Štefko,2012 Možnosti predikcie správania manažérov pri zvládaní náročných situácií v manažérskej práci - In: Ekonomický časopis. - ISSN 0013-3035. - Roč. 60, č. 8 (2012), s. 835-853.

Lisý, J. a kol. 2005. Ekonómia v novej ekonomike. 1. vyd. Bratislava: IURA EDITION. ISBN 80-80787-063-3.

Lénártová, Gizela, 2013. Boj proti daňovým podvodom a daňovým únikom. In: Finančný manažér. Roč. XIII., č. 2, s. 21-28. ISNN 1335-5813.

Mažáry, M. 2014. Prehl'ad vykonaných kontrol a efektivity podla daňových úradov za obdobie rokov 2008 až 2012. Finančné riaditel'stvo SR.

Paulik, D., E. Beňová, I. Bondareva a kol. 2012. Základy financií a meny. Bratislava: VŠEMVS. ISBN 978-80-89600-06-9.

Rajnoha,R., J.Dobrovič,2011, Simultaneos Management of Economics Business Processes by Added Value Knowledge. E \& M EKONOMIE A MANAGEMENT, 14/1, 53-69

Rajnoha, R., A. Sujová, J. DOBROVIČ, 2012, Management and Economics of Business Processes Added Value. World Conference on Business, Economics and Management (BEM-2012) Book Series: Procedia Social and Behavioral Sciences, 62 , 1292-1296.

Rajnoha,R.,D. Slivková,J. Dobrovič, 2014, Globatization and Transer Pricing in Multinational Corporations in Slovakia and OECD Countries - Analytical Study and Decision-Making Model on the Choiceof Optimal Transfer - Pricing Method. Ekonomicky Časopis, 62/6, 609-630

Sivák, R. a kol. 2007. Verejné financie. 1. vyd. Bratislava: IURA EDITION. ISBN 978-80-8078-094-4. 
Schultzová, A. a kol. 2011. Daňovníctvo - daňová teória a politika I. 1. vyd. Bratislava: IURA EDITION. ISBN 978-80-8078407-2.

Schultzová, A. a kol. 2009. Daňovníctvo. 2. vyd. Bratislava: IURA EDITION. ISBN 978-80-8078-264-1 76.

Schultzová, A. 2004. Daňovníctvo v Slovenskej republike. Bratislava: Súvaha. ISBN 80-88727-77-4.

Schultzová, Anna, 2005. Spolupráca členských štátov Európskej únie pri odhal'ovaní daňových podvodov. In: Ekonomický časopis. Roč. 53, č. 3, s. 308-313. ISSN 0013-3035.

Srnková, J. 2014. Medzinárodná administratívna spolupráca. Finančné riaditel'stvo SR

Široký, J. a kol. 2008. Daňové teorie s praktickou aplikací. 2. Vyd. Praha: C. H. Beck. ISBN 978-80-7400-005-8.

Trojanek M., (2015) "Strategic municipal real estate management", Journal of International Studies, Vol. 8, No 2, 2015, pp. 9 17. DOI: $10.14254 / 2071-8330.2015 / 8-2 / 1$.

Vyšňovská, J. a kol. 2005. Daňová sústava. 1.vyd. Prešov: Vydavatel'stvo Michala Vaška. ISBN 80-7165-525-2.

Я. Добрович, Прешовський університет (Прешов, Словаччина);

A. Корауш, Пан'європейський університет у Братиславі (Братислава, Словаччина);

P. Райноха, Пан'європейський університет у Братиславі (Братислава, Словаччина).

Формування системи управлінських заходів щодо стійкої протидії податковим махінаціям та ухилянню від сплати податків: співставлення практик Словаччини та ЕС

Дослідження присвячено визначенню шляхів посилення боротьби з податковими шахрайствами та ухиленнями від сплати податків в цілому в ЄС та в Словаччині зокрема. Для досягнення цієї мети досліджено системи та механізми здійснення контролю за податками. Автори проаналізували діяльність податкових органів та визначили основні шляхи боротьби з податковими шахрайствами та ухилянь від сплати податків. Аналіз даних системи VIES ma Eurostat дозволив дослідити обсяаи ухилянь від сплати податків в Словаччині та деяких інших країнах-членах ЄС, а також їх частку в загальних податкових зобов'язаннях. Авторами запропоновано запровадити систему міжнародного обміну податковою інфрормацією між країнами ЄC та системою VIES. Дана система передбачає узагальнення та структуризацію інфрормації про підприємства країн-членів ЄC та даних Eurostat. Результати кластерного аналізу показали, що обсяг ухилянь від сплати податків (зокрема, за податком на додану вартість) в Словаччині $\epsilon$ одним з найнижчих серед країн ЄС. Авторами встановлено, що система сплати податку на додану вартість надає можливості уникнути податкових зобов'язань, що провокує появу низки податкових шахрайств та ухилянь від сплати податків. У статті запропоновано систему попереджувальних заходів та роз'яснювальної роботи з платниками податків на додану вартість у Словацькій Республіці та деяких країнах-членах ЄС. Підвищення ефеективності боротьби з ухиленнями від сплати податків та податковими шахрайствами може бути здійснено шляхом прийняття заходів обов'язкового створення рівноправних бізнес-рахунків, створення реєстру итрасрів окремих платників податків, запровадження єдиної ставки податку на додану вартість, скасування податку на додану вартість в деяких випадках та запровадження податку з обороту.

Ключові слова: податок; платники податків; податкове шахрайство; ухилення від сплати податків; пДВ; Словаччина; Європейський Союз. 